Tarih Kültür ve Sanat Araştırmaları Dergisi

Revue des Recherches en Histoire Culture et Art

مجلة البحوث التاريخية والثقافية والفنية
Vol. 6, No. 3, June 2017

Copyright (C) Karabuk University

http://kutaksam.karabuk.edu.tr

\title{
DOI: 10.7596/taksad.v6i3.911
}

Citation: Sülün, E. (2017). The Significance of Aptitude Tests in the Selection of Prospective Music Teachers. Journal of History Culture and Art Research, 6(3), 49-64. doi:http://dx.doi.org/10.7596/taksad.v6i3.911

\section{The Significance of Aptitude Tests in the Selection of Prospective Music Teachers}

\section{Erkan Sülün ${ }^{1}$}

\begin{abstract}
In Turkey and North Cyprus, music education departments are usually situated in faculties of education. The eligibility requirements are in two stages: Applicants who manage to attain the required minimum grade from Transition to Higher Education Examination can then take an aptitude test. These aptitude tests are designed by each university department to assess applicants' qualifications. The main objective of this study is to examine the content and the structure of the aptitude test, and accordingly to be able to shed a light on the correlation between students' aptitude tests scores and music and pedagogy course grades. For this purpose, the scores of 29 students who successfully passed the aptitude test in the Music Education Programme at Eastern Mediterranean University are compared with their course grades. This study employs quantitative descriptive research with an inter-relational submodel. The Pearson correlation coefficient is used whilst analysing the relationship. The sampling method has been chosen for purposive sampling. This study determines both the content and predictive validity of the Music Education Department’s aptitude test.
\end{abstract}

Keywords: Aptitude tests, Assessment in Music Education, Music Education Departments, Music Teacher Education, Music teacher selection.

\footnotetext{
${ }^{1}$ Yrd. Doç. Dr., Yakın Doğu Üniversitesi, Atatürk Eğitim Fakültesi, Müzik Öğretmenliği Bölümü, Kıbrıs. Email: eerkansulun@gmail.com
} 


\section{Introduction}

The 'teacher' is one of the most significant elements of the educational process. Varış (1973) explains that teachers are important because they are the ones who implement state's education policies, shape those policies with their invaluable feedbacks, involve and contribute to the research pillar of the overall educational policies. It is possible to say that, the quality of the education in schools is affected positively by improvements in the quality of a teacher education system (Ballantyne, 2007; Carter, Carre ve Bennett, 1993; DarlingHammond, 2000).

The most important dimension of the educational process is the education policies of the states. It can be argued that the depth, the extent of the organization and the sustainability of the education policies determine the success of the overall educational system. In this context, there are four main components of an educational process. These are the program, the teacher, the student and the physical conditions surrounding that particular learning environment such as building, equipment and facilities. When the countries who achieved success in the international arena during the last thirty years, it is seen that one of the most important reasons behind their success is the changes they managed to implement in terms of their teacher education systems.

In any society where teachers and teaching as an occupation remain weak, even the most advance educational equipment and facilities would turn out to be fruitless. Akyüz (2000) argues that as long as the main problem in relation to education is not considered to be the endeavour of creating competent teachers, it will not be realistic to think that education will substantially contribute to communal and societal development. United Nations Educational, Scientific and Cultural Organization (2012) report on teacher education strategies is enlightening in this fashion. According to the report, the requirement for competent teachers is a very important problem mostly in developing countries.

There are number of studies published in international journals that can be considered as sources of inspiration for this research. They aim to develop an in-depth understanding of the Turkish music teacher education system. Among these studies are: (i) Guven’s (2015) study into levels of music performance anxiety and test anxiety of Turkish prospective music teachers in piano exams; (ii) Gokturk's (2010) research into the status of string teacher education at university music teacher training schools in Turkey; and (iii) Ersozlu, Nietfeld and Huseynova's (2015) research into predicting preservice music teachers' performance success in instrumental courses using self-regulated study strategies and predictor variables which investigate Turkish music education undergraduate programmes. The studies which examined music teacher education in different countries also considerably strengthened this 
research by providing an international perspective of music teacher education systems. They include Güsewell, Joliat ve Terrien (2016); Johansen ve Brøske Danielsen (2012); Mateiro (2010); Southcott ve Joseph (2010); Thorgersen, Johansen ve Juntunen (2016); and Watson (2010). This research aims to build on that literature by providing invaluable insights from Turkey and North Cyprus. The following chapter provides background knowledge on music education programmes in these two cases.

\section{Music Teacher Education System in Turkey and North Cyprus}

In Turkey, music education programmes have been constantly searching for a model and standardization. Since 1924, the year of the establishment of the Musiki Muallim Mektebi translated as Music Teacher's School as the first institution providing music teaching education in Turkey (Yayla, 2004) up until today, many changes took place in music education programmes at various universities. In 1998, an important decision was taken in that respect. The Council of Higher Education (Yüksek Öğretim Kurulu, YÖK) entitled a single and a common music education programme to be followed by all related institutions in Turkey (Barışeri, Özdek, \& Can, 2006; Kalyoncu, 2005; YÖK, 1998). Neverthless, according to Kalyoncu (2005), the new programme fails to reflect a complete educational programme and remains rather descriptive. It only covers name and content descriptions of the courses. Moreover, the Council of Higher Education proposed the central adoption of the programme by all higher educational institutions with no further room for any individual changes which may be demanded by universities. It is possible to say that, the rational of the decision at that time were both the standardization and the centralization of the programme in general. The first music education department in North Cyprus was founded in 2006 in EMU. This programme has been used in all music education departments since then.

Universities' music education departments, which can be found within the faculties of education, provide music education programmes both in Turkey and North Cyprus. Graduates from music departments or conservatoires can acquire the eligibility to become teachers upon the completion of related post-graduate programmes. These are practically oriented and do not require dissertation writing. As mentioned elsewhere, this paper focuses on the undergraduate music education programmes. There are twenty-five music education departments in Turkey. In addition to those, there are two more departments in North Cyprus which do also adopt the same curriculum. It is interesting to note that although those programmes are similar in their entrance requirements, entrance exams differ greatly from each other. There is a central university entrance exam which involves two stages. Students who would like to continue 
their higher education in Turkish and North Cyprus universities require sitting for this exam following the completion of their high school education.

The first stage of the entrance exam is Transition to Higher Education Examination, and the second stage is the Undergraduate Placement Exam. To be able to have the aptitude tests of the undergraduate music education programmes, students require holding a sufficient grade obtained from the Transition to Higher Education Examination in subject areas of Language, Maths, Science, Social Sciences, and Philosophy. Each year, according to the results of the Transition to Higher Education Examination, universities determine the minimum score for accepting students for their individual entrance examinations. Therefore, scores may differ between universities. Once the minimum grades are determined, universities plan their own entrance exams accordingly.

\section{The Structure of the Aptitude Test}

The Aptitude Test for the Music Teacher Programme is designed to measure students' abilities in four different areas. It is called Music Education Undergraduate Programme Entrance Aptitude Test (MEUPEAT). These areas are listed as Listening, Singing, Playing, and the Interview.

Figure 1. Music Education Undergraduate Programme Aptitude Test (MEUPEAT)

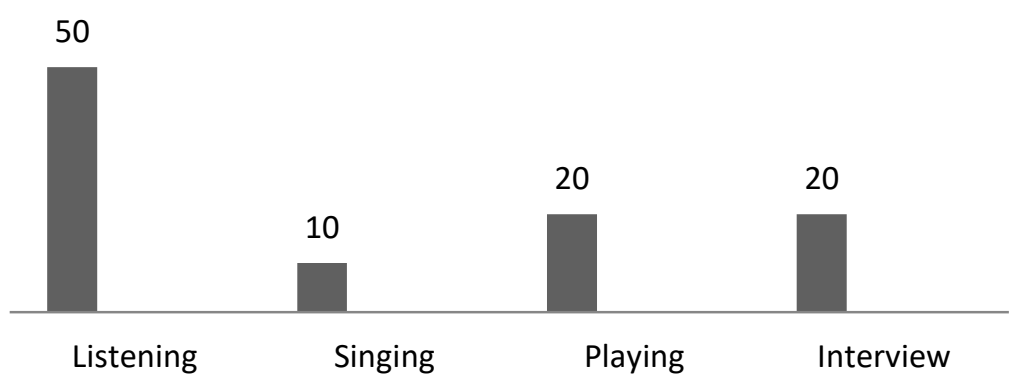

The Listening, Singing and playing categories designed to measure students' musical abilities for music lessons in the programme and the total weight of these three categories is 80 per cent of the aptitude test. The Interview category designed to measure both students' speaking abilities and capability of further educational performances. The total weight of the interview category is 20 per cent of the aptitude test. 


\section{Music Education Undergraduate Programme (MEUP)}

Based on Music Education Programmes, courses can be listed under three main headings. These areas are Music Lessons, Pedagogy Lessons, and General Culture Lessons.

Figure 2. Music Education Undergraduate Programme (MEUP) Course Credits

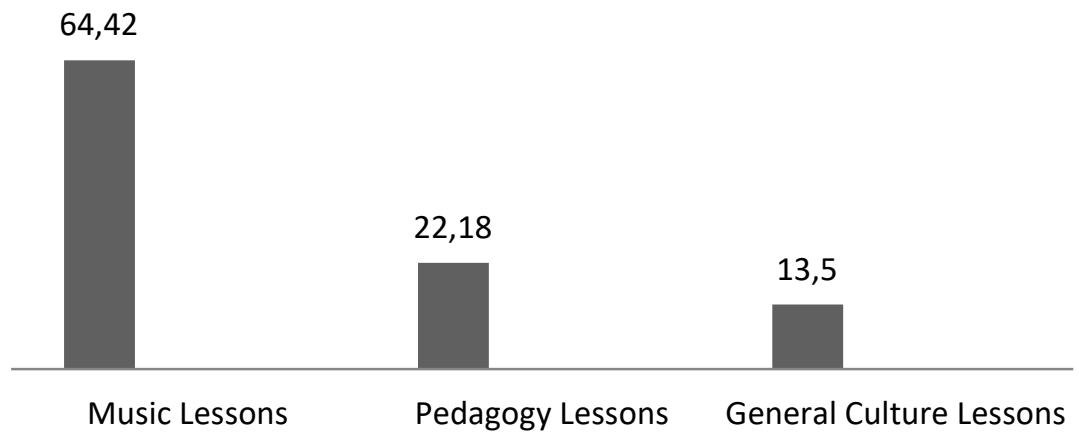

Sixty-four per cent of the Music Education Programme consists of music courses. 22, 18 per cent of the Music Education Programme consists of pedagogy courses, and 1.5 per cent of the Music Education Programme consists of general culture courses.

When the content of the aptitude test is considered, it is seen that the students' abilities which are addressed and improved throughout the programme are measured only up to a certain degree. It is possible to argue that there are some limitations within the content of the test. For example, the course named as the "Music Theory" has the highest credit among the other courses within the Department of Music Teacher Programme. In parallel to that, musical hearing is the most important part of the aptitude test. Hence, there is no evaluation of the "solfeggio" which has an important role within the content of the Music Theory course. Besides that, there is no measurement of the level of the students' music theory. With regard to singing and playing, there is only a measurement in terms of performance. It is observed that the ability of sightseeing in terms of singing and playing is not measured either. Besides that, it can be argued that spontaneous abilities which can also provide the grounds for the measurement of the musical abilities, creativity and theoretical knowledge are not measured either. It is seen that the measurement of the "pedagogy" courses which is one of the most important within the Music Teacher programme in general is also quite limited. During the interview which is the 20 per cent of the overall examination, the main objective is to identify different abilities as well as student's view on music teaching and music teacher education in general. 
As discussed above, there can be gaps between aptitude tests and programmes. For a better projection on that particular issue in cases of Turkey and North Cyprus, this study mainly assesses the success of the measurement tools applied at aptitude tests by comparing scores obtained by students from the aptitude test with their further academic grades in music lessons available in the curriculum. For this purpose, in total the grades of 29 students were evaluated who successfully passed the entrance exam of the Eastern Mediterranean University, Music Education Programme. Accordingly, the following questions were asked:

1. Is there any relationship between the scores music teacher candidates obtained from the aptitude test and their academic success?

2. To what extent the undergraduate programme courses which are thought as relevant to the sub-dimensions of the aptitude test are related to the basic elements tested in the exam. For example musical hearing, playing, and pedagogy?

3. To what extent the overall score of the aptitude test is related to the cumulative Grade point average (GPA) at the end?

\section{Methodology}

This study employs quantitative descriptive research with an inter-relational submodel. Grades from a number of cohort of classes are considered while establishing the relationship between two variables: The overall score of the aptitude test and GPA the musical hearing score at the aptitude test and the grades of the musical hearing courses; the instrument playing score at the aptitude test and the grades of the instrument courses; and the interview score at the aptitude test and the grades of the pedagogy courses.

\section{Participants}

Participants of this study were composed of Eastern Mediterranean University Music Teaching Department's 29 students. 51,72 per cent of the overall participants are women and 48,28 per cent of the overall participants are men. The average age of participants is $21,58 \pm 1,29$, where the youngest participant is 20 years old, and the oldest one is 26 years old. During the research, 31 per cent of the participants were in their Second Year of the undergraduate programme, where 69 per cent were in their Third Year.

The sampling method is chosen to be a purposive sampling. Reasons for this can be explained as below: 
i. The researcher worked at the Eastern Mediterranean University between the years 2012 and 2015;

ii. The researcher took part in the entrance exams of the Music Department;

iii. The researcher has had first-hand experience of the assessment process;

iv. The researcher has an adequate experience on the topic.

The data of the First Year students is not incorporated into the study mainly because their grades were not available during the data collection period of the research. Fourth Year students were not also part of the study as their grades were not accessible any longer alongside the document destruction policy of the University every three years.

\section{Data Collection Process}

The Aptitude Test scores and the grades obtained from the courses are the data of this study. Twenty-nine of the course scores of Second and Third-year students were accessed via the university portal under the surveillance of students' advisors. The Aptitude Test scores were accessed via the Archive of the Education Faculty. The data was collected in January, 2015.

\section{Data Analysis}

In this study, descriptive statistics are employed. The average of aptitude test scores and course grades (GPA), their standard deviation, the highest and the lowest grades are all presented as related tables. Besides that, paired t-test is employed to determine whether there is any difference between scores students obtained at the aptitude test and their course grades. In this context, it is evaluated whether there is a meaningful difference between the aptitude test scores and the course grades. The evaluation is made on the bases of "musical hearing", "playing”, and "pedagogy" scores. Finally, the relationship between the course grades and the aptitude test scores is analysed. Before calculating the relationship between the aptitude test scores and the course grades, it is evaluated whether the data is normally distributed or not. Later, it is found that the data is normally distributed in this study. Accordingly, a Pearson correlation coefficient is used while analysing the relationship. 


\section{Results}

Table 1. Descriptive Statistics of Students’ MEUPEAT Grades and Course Grades

\begin{tabular}{lccccc}
\hline & $\mathrm{N}$ & $\bar{x}$ & $\mathrm{~S}$ & Min & Max \\
\hline MEUPEAT Scores & 29 & 77,41 & 11,12 & 57,00 & 98,00 \\
Musical Hearing & 29 & 73,83 & 11,08 & 60,00 & 95,00 \\
Instrument & 29 & 80,52 & 11,60 & 55,00 & 100,00 \\
Interview & 29 & 80,69 & 10,67 & 60,00 & 100,00 \\
\hline GPA & 29 & 70,90 & 7,15 & 53,33 & 87,33 \\
Musical Hearing & 29 & 68,28 & 12,20 & 45,00 & 91,00 \\
Instrument & 29 & 80,90 & 11,25 & 50,00 & 95,00 \\
Pedagogy & 29 & 63,52 & 6,80 & 47,00 & 76,00 \\
\hline
\end{tabular}

As can be seen from Table 1, MEUPEAT scores and course grades of the students covered by research. According to the table above; when the MEUPEAT scores of the students are examined, it is found that the average of MEUPEAT total scores is $77,41 \pm 11,12$, the average of MEUPEAT musical hearing scores is $73,83 \pm 11,08$, the average of MEUPEAT instrument scores is $80,52 \pm 11,60$, and the average of MEUPEAT interview scores is $80,69 \pm 10,67$.

However; when students' course grades are examined, it was determined that the average of MEUP Musical Hearing Course grades is $68.28 \pm 12.20$, the average of MEUP Instrument Course grades is $80,90 \pm 11,25$, the average of MEUP Pedagogy Course grades is $63,52 \pm 6,80$; and the average of the students' grade points (GPA) is $70,90 \pm 7,15$. 
Table 2. The Comparison of the MEUPEAT Scores and MEUP Course Grades

\begin{tabular}{|c|c|c|c|c|c|c|}
\hline & Grades & $\mathrm{n}$ & $\mathrm{X}$ & S & $\mathrm{T}$ & $\mathrm{P}$ \\
\hline \multirow{3}{*}{ Musical Hearing } & Aptitude T. Scores & 29 & 73,83 & 11,08 & \multirow{3}{*}{2,48} & \multirow{3}{*}{$0,02 *$} \\
\hline & & & & & & \\
\hline & Course Grades & 29 & 68,28 & 12,20 & & \\
\hline \multirow{3}{*}{ Instrument } & Aptitude T. Scores & 29 & 80,52 & 11,60 & \multirow{3}{*}{$-0,16$} & \multirow{3}{*}{0,88} \\
\hline & & & & & & \\
\hline & Course Grades & 29 & 80,90 & 11,25 & & \\
\hline \multirow{3}{*}{ Pedagogy } & Aptitude T. Scores & 29 & 80,69 & 10,67 & \multirow{3}{*}{9,13} & \multirow{3}{*}{$0,00 * *$} \\
\hline & & & & & & \\
\hline & Course Grades & 29 & 63,52 & 6,80 & & \\
\hline
\end{tabular}

Table 2 shows the results of paired sample t-test on comparison of MEUPEAT scores and MEUP course grades of the Musical Hearing and Instrument Courses of the students, who participated in the research. When Table 2 is examined it is seen that the average of the MEUPEAT Musical Hearing test scores of the participating students are 73,93 $\pm 11,08$ and the average of the MEUP Musical Hearing course grades are $68,28 \pm 12,20$. It is determined that this difference between the average of the students' aptitude test scores and the average of the students' course grades is statistically significant and the students' Musical Hearing Test scores in the aptitude test are found to be statistically significantly higher than the Musical Hearing course grades $(\mathrm{p}<0,05)$.

It is also determined that there is no statistically significant difference between the average of the students' Instrument Aptitude test scores and the average of the students' Instrument Course grades ( $>>0,05)$. The Aptitude Test scores and the Course Grades' of students are similar.

It is seen that, the average of the MEUPEAT Pedagogy scores of the participating students are $80,69 \pm 10,67$ and the average of the MEUP Pedagogy Course grades are $63,52 \pm 6,80$. This difference between the average of the students' test scores and the average of the students' pedagogy course grades is found to be statistically significant $(p<0,05)$. 
Pedagogy Test scores of the students are found to be statistically significantly higher than the Pedagogy Course grades.

Table 3. The Correlation between Students’ Aptitude Test Grades and Course Grades

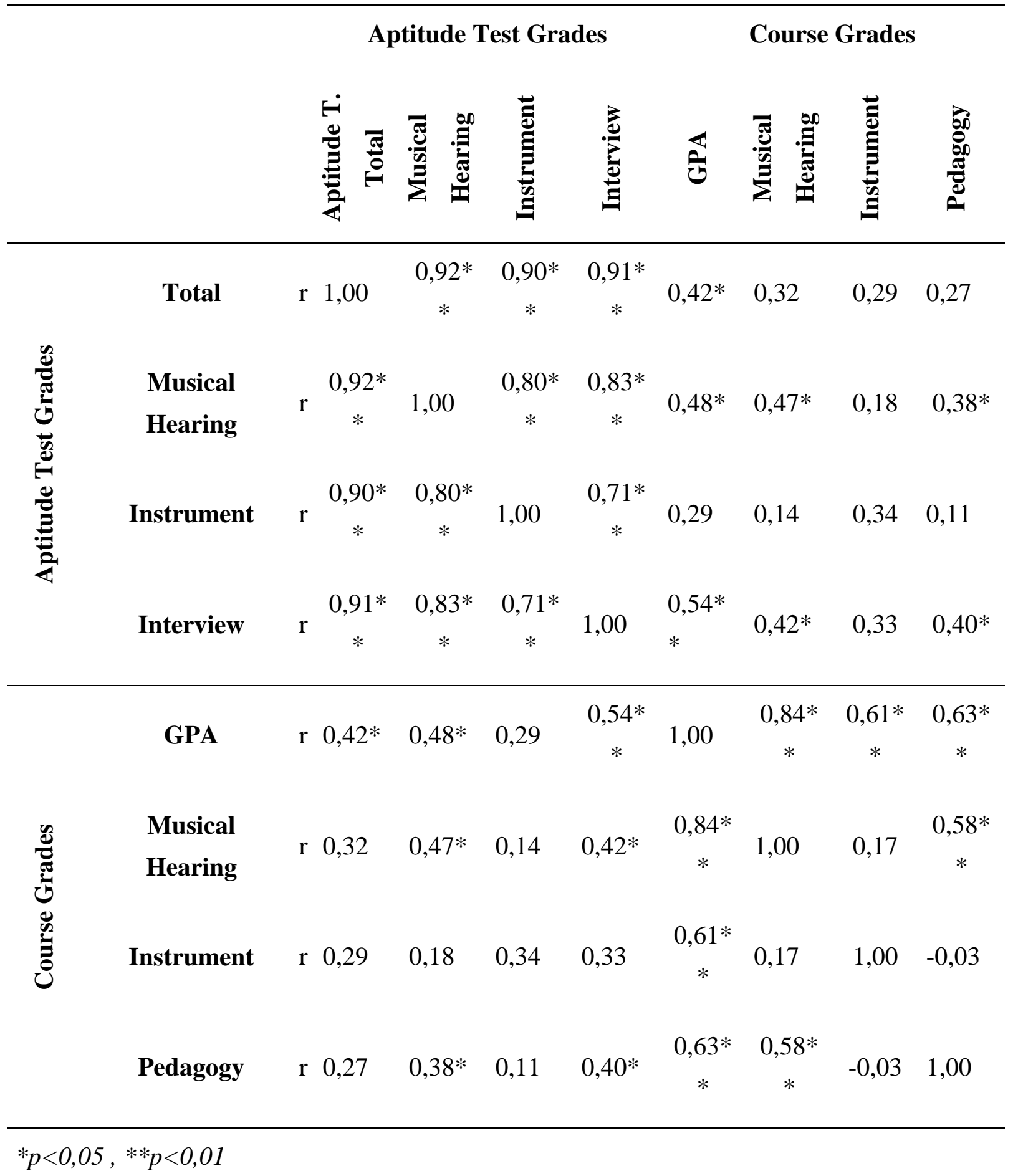


Table 3 shows the results of Pearson Correlation analysis for determining correlations between MEUPEAT scores and MEUP course grades of the participating students in the research.

When Table 3 is examined; it is observed that there is a statistically significant correlation between the students' total scores of the MEUPEAT and the students' Musical Hearing, Instrument and Interview scores of the MEUPEAT $(\mathrm{p}<0,05)$. There are also statistically significant, positive and strong correlations between students' MEUPEAT Musical Hearing scores and the MEUPEAT Instrument and Interview scores $(p<0,05)$.

There is no statistically significant correlation between MEUP Musical Hearing grades and MEUP Instrument grades of the participating students in the study ( $p>0,05)$, and there is a statistically significant positive and moderate correlation between MEUP Musical Hearing grades and MEUP Pedagogy grades $(p<0,05)$. As the grades of the students' Musical Hearing Courses increase, students' Pedagogy Course grades increase in parallel to that. It is seen that there is no statistically significant correlation between the grades of the students' MEUP Instrument Courses and the grades of the students’ MEUP Pedagogy Courses.

There are statistically significant, positive and strong correlations between the GPA of students and the MEUP Musical Hearing, Instrument and Pedagogy Courses grades $(p<0,05)$. As the grades of the students' Musical Hearing, Instrument and Pedagogy courses increase, students' GPA also increases in a parallel fashion.

It is determined that there is a statistically significant correlation between the MEUPEAT total scores and the MEUP GPA of participating students in the study $(p<0,05)$. This correlation is positive and moderately strong. As the total scores of the students from the MEUPEAT increase, the GPA also increases. In addition, it is determined that there are statistically significant and positive correlations between the MEUPEAT Musical Hearing scores and the Interview scores and the MEUP Musical Hearing Course grades, Pedagogy Course grades and the GPA.

\section{Discussion and Conclusion}

When descriptive statistics are analysed in terms of students' course grades and their aptitude test scores, it is noted that the aptitude test scores of the music teacher candidates who are accepted for the music teaching programme varies between 57,00 and 98,00. The wide range between the lowest and the highest total scores in the aptitude test obtained by those students who are accepted for the programme indicates the difference between the levels of students' musical abilities. The fact that the students in the same educational programme 
are actually quite diverse in terms of their musical abilities signifies two undesirable circumstances for the classes shared by all of them at the same time. First and foremost, those students who obtain high scores in their aptitude tests may need to wait for a certain period of time for those who has less musical abilities to develop themselves in that manner. This situation may lead to a loss of time for those students with higher abilities and would also create a lack of motivation for them. In a similar vein, as the second point, if classes are designed for those with higher musical abilities, those with less musical abilities initially would be negatively affected in terms of their course grades. Under such conditions, it can be said that students' anxiety levels may increase and they can possibly experience the feeling of a failure to a greater extent.

In the sample, North Cyprus Eastern Mediterranean University analysed by this study, it is noted that all of the candidates who managed to obtain the minimum score of the aptitude test were accepted to the undergraduate music teaching programme. In a report prepared for Stanford University, Sahlberg (2010) highlights the required conditions for becoming a music teacher in Finland. According to his report, it is not sufficient to be a high school graduate and pass the matriculation exam. Candidates should obtain the highest scores and should have nearly flawless personal abilities. In the same report, it is also noted that, in Finland, each year only one out of ten applications are accepted by universities to related programmes for becoming a teacher. Those researchers who adopt a similar perspective and analyse different cases across the globe indicate the importance of the selection of candidates for music teaching programmes and they further highlight how educational outcomes may be influenced by this selection process (Ballantyne, 2001; Ballantyne, \& Packer, 2004; Colwell, 2006). When it is considered that the minimum score is 50 in the aptitude test and 57 is the lowest score obtained by those who are accepted for the programme, it can be said that the goal is not to select candidates with high qualities and enviable personable aptitudes. Furthermore, it can be said that the aptitude test for the music teaching department does not meet the standards in terms of the principles of measurement and evaluation. Moreover, it can be argued that even those students who obtained only slightly higher scores than the minimum are accepted for the programme.

When scores obtained from hearing, performance and pedagogy are compared with course grades, it is seen that scores obtained from the performance part of the entrance exam aptitude test and the average of the grades obtained from the performance courses throughout the undergraduate programme are almost equal to each other. According to that, it can be said that the measurement tool for the performance related ability of candidates during the aptitude test is an adequate one in terms of the competency of the programme. Then again, there is 
over five point differences between hearing scores obtained from the entrance exam aptitude test and course grades obtained from the hearing courses. When the contents of both the aptitude tests with respect to the hearing part, and the course on hearing are analysed, it is seen that the aptitude test is based on reflection (mere hearing and repeating). Whereas, in hearing courses the desired outcome is to teach how to name these perceived sounds in more of a theoretical term such as intervals, chords, solfeges and dictation. It is seen that reflection is not among the outcomes desired by these courses. It can be argued that asking descriptive questions at the entrance exam is important in determining the level of students' knowledge in determining perceived sounds. A design of the musical hearing part of the aptitude test as descriptive and theoretical questions can be an advantage for the acceptance of those students who already have high readiness for musical hearing courses. The most noticeable difference between the scores obtained at the aptitude test and the course grades is observed to be between the scores they got from the part of the test which aimed to take note of students' perspectives on teaching as an occupation and to measure a number of interpersonal skills and the pedagogy courses. It is seen that those students who has the average score of 80,69 from the aptitude test interview, has the average grade of 63,52 from their pedagogy classes. In the light of these findings, it can be said that the measurement tool of the pedagogy part of the aptitude test has serious limitations with respect to the measurement of skills in that particular area.

In terms of the entrance exam, when the content of the interview part of the aptitude test is considered, it is seen that it is designed to understand perspectives of candidates in: visa-vis teaching; measuring their ability of explaining themselves clearly; observing candidates' behaviour, body language, and oral communication skills. At this point, it can be said that it is important to analyse both approaches in different countries, and approaches which holds different perspectives. In a similar vein, it is also important to examine approaches regarding pedagogy within the aptitude tests. Finland, Sibelius Academy, Music Education Department (University of Arts Helsinki, 2016), stated that the pedagogy part of the entrance exam consists of these stages. These are: teaching experience in which the topic is provided 30 minutes prior to the teaching demonstration; presentation such as a sample of teaching; and an essay on self-reflection afterwards the presentation. Regarding the entrance exam of the music education department in Finland, Sulun (2015), points out that, the assessment of candidates' abilities within the field of pedagogy has a positive impact on the clarification of the dilemma which music teaching candidates usually have with respect to the "musicianship versus music teaching” even at the very early stages of their acceptance for the programme. In the same place, he also highlights the urgency of re-designing of the aptitude tests in Turkey and in North Cyprus to make them more responsive to the dilemma mentioned above. 
A closer scrutiny of the results reveals that relations between the average points of the aptitude test scores and the course grades throughout the undergraduate degree are in positive direction, moderate and strong both in terms of the sum of the overall grades as well as scores for each area. It is possible to say that the moderate relationship between the overall aptitude test and the GPA is not a sufficient one. The assessment made in the aptitude test has to foresee/ predict students' academic success throughout the programme.

It is seen that there is a moderate relationship between the results of the interview part of the aptitude test and aptitude test overall scores. Based on research findings, it can be said that the interview part, which is poorly devised as an assessment tool, directly affects both the overall mark of the aptitude test and the selection of the candidates. As Bowles, Hattie, and Dinham (2014) indicate, poor selection of prospective teachers would have cause personal and institutional costs. Darling-Hammond (2006), in his study on the significance of the teacher education, also claims that selection of prospective teachers is vastly important in terms of the success of overall system of teacher education. Accordingly, when the quality of the teacher education system is considered in the context of North Cyprus, it can be argued that it is essential to correctly assess the abilities and the knowledge level of prospective teachers before they become a part of any undergraduate programme.

Similar to all other teaching education departments, a selection of students for music teaching education is a tremendously important process. Assessment tools designed for selecting prospective music teachers should be scrutinized, analysed, evaluated and accordingly developed. Evaluation processes as such have to be repeated in certain intervals, with the consideration of changing conditions and variables. Observations regarding students' academic success and the level of their adaptation to the system have to be also taken into account while repeating these evaluation processes. This study reveals that the assessment tool under scrutiny has limitations in the sense that it does not assess certain areas or it does so only up to a certain degree. In the view of that, it can be proposed that the analysed aptitude test has to be revised alongside the aforementioned deficiencies and re-designed accordingly. 


\section{References}

Akyüz, Y. (2000). Türk Eğitim Tarihi. Ankara: Milli Eğitim Bakanlığı.

Ballantyne, J. (2001). The distinctive nature of music education and music teacher education. In P. Singh \& E. McWilliam (Eds.), Designing educational resarchers: Theories, methods and practices. Flaxton, QLD: Post Pressed.

Ballantyne, J. \& Packer, J. (2004). Effectiveness of preservice music teacher education programs: Perceptions of early-career music teachers. Music Education Research, 6(3), 299-312.

Ballantyne, J. (2007). Integration, contextualization and continuity: three themes for the development of effective music teacher education programmes. International Journal of Music Education, 25(2), 119-136.

Barber, M. \& Mourshed, M. (2007). How the world's best-performing school systems come out on top. London, UK: McKinsey and Company.

Barışeri, N.; Özdek, A. \& Can, M. (2006). "Müzik öğretmenliği lisans programı geliştirme çalışmaları." Paper presented at the National Music Education Symposium, University of Pamukkale, Denizli, Turkey.

Bowles, T.; Hattie, J. \& Dinham, S. et al. (2014). Proposing a comprehensive model for identifying teaching candidates. Australian Educational Researcher, 41, 365-380.

Carter, D. S. G.; Carre, C. G. \& Bennett, S. N. (1993). Student teachers' changing perceptions of their subject matter competence during an initial teacher training programme. Educational Research, 35(1), 89-95.

Colwell, R. (2006). Music Teacher Education in This Century: Part II. Arts Education Policy Review, 108 (2), 17-32.

Darling-Hammond, L. (2000). How teacher education matters. Journal of Teacher Education. 51(3), 166-173.

Darling-Hammond, L. (2006). Powerful teacher education: lessons from exemplary programs. San Francisco: Wiley.

Ersozlu, N. Z.; Nietfeld, J. L. \& Huseynova, L. (2015). Predicting preservice music teachers' performance success in instrumental courses using self-regulated study strategies and predictor variables. Music Education Research. Published online on October 11, 1-10.

Gokturk, D. (2010). Current status of string teacher education at university music teacher training schools in Turkey. International Journal of Music Education. 28(2), 176-192.

Gurlen, E. \& Demirel, Ö. (2010). “Avrupa Birliği ve Türkiye'deki öğretmen yeterliklerin karşılaştırmalı incelenmesi.” Proceedings of International Conference on Teacher Training Policies and Problems II, 396-401. University of Hacettepe, Ankara, Turkey.

Güsewell, A.; Joliat, F. \& Terrien, P. (2016). Professionalized music teacher education: Swiss and French students' expectations. International Journal of Music Education. Published online on October 19. 
Guven, Elif (2015). Levels of music performance anxiety and test anxiety of Turkish prospective music teachers in piano exams. International Journal of Music Education. First published on December 31, 1-11.

Johansen, G. \& Brøske Danielsen, B. A. (Eds.). (2012). Educating music teachers in the new millennium. Oslo, Norway: Norwegian Academy of Music.

Kalyoncu, N. (2005). Eğitim Fakültelerinde Uygulanan Müzik Öğretmenliği Lisans Programının Revizyon Gerekçeleriyle Tutarlığı. Gazi Eğitim Fakültesi Dergisi, 25(3), 207-220.

Mateiro, T. (2010). Education of music teachers: A study of the Brazilian higher education programs. International Journal of Music Education. 29(1), 45-71.

Sahlberg, P. (2010). The Secret to Finland's Success: Educating Teacher. Retrieved from Stanford Center for Opportunity Policy in Education, Research Brief: https://edpolicy.stanford.edu/sites/default/files/publications/secretfinland\%E2\%80\%99s-successeducating-teachers.pdf

Sayg, C. (2009). Aktif ögrenmenin müzik tarihi dersine iliş̧kin başarı, tutum ve özyeterlik üzerindeki etkisi. PhD Thesis, University of Dokuz Eylül, İzmir, Turkey.

Senturk, N. (2001). Musıki Muallim'den günümüze müzik öğretmeni yetiştiren kurumlar. Gazi Eğitim Fakültesi Dergisi, 21(2), 135-142.

Southcott, J. \& Joseph, D. (2010). Engaging, exploring, and experiencing multicultural music in Australian music teacher education: The changing landscape of multicultural music education. Journal of Music Teacher Education, 20(1), 8-26.

Sulun, E. (2015). The Comparative Analysis of Music Teacher Education Systems of Turkey, Canada, England, Finland and Germany. (Unpublished doctoral dissertation). Gazi University, Turkey.

Thorgersen, C. F.; Johansen, G. \& Juntunen M. L. (2016). Music teacher educators' visions of music teacher preparation in Finland, Norway and Sweden. International Journal of Music Education. 34(1), 49-63.

University of the Arts Helsinki, Sibelius Academy. (2016). Retrieved from http://www.uniarts.fi/sites/default/files/Valintaopas2017_KandiMaisteri.pdf on 24 September 2016.

Unesco (2012). Unesco strategy on teachers (2012-2015). Retrieved from http://unesdoc.unesco.org/images/0021/002177/217775e.pdf on 10 May 2014.

Varis, F. (1973). Eğitimde program araştırmaları. Ankara Üniversitesi Eğitim Bilimleri Fakültesi Dergisi.

Watson, A. (2010). Musicians as instrumental music teachers: Issues from an Australian perspective. International Journal of Music Education. 28(2), 193-203.

Yayla, F. (2004). "Musiki Muallim Mektebinden günümüze müzik öğretmeni yetiştiren kurumlar ve müzik öğretmeni yetiştirme yaklaşımları 1şığında genel durum” [Music teacher training institutions from their foundation to the present]. Paper presented at Symposium on Training Music Teachers from Music Teacher Schools to Present, Süleyman Demirel University, Isparta. Retrieved May 24, 2015, from http://www.muzikegitimcileri.net 